\title{
ECONOMY
}

\section{ESSENTIAL CHARACTERISTICS OF THE ECONOMIC SECURITY OF THE STATE AND ITS MAIN COMPONENTS}

\author{
Golovko Vladyslav \\ State educational-scientific institution «Academy of Financial Management», Kyiv, Ukraine
}

DOI: https://doi.org/10.31435/rsglobal_ws/30112019/6778

\section{ARTICLE INFO}

Received: 14 September 2019

Accepted: 22 November 2019

Published: 30 November 2019

\section{KEYWORDS}

security,

economic security,

economic security of the state,

components of economic security of the state,

level of economic security.

\begin{abstract}
The historical aspects of the development of economic security are considered. The hierarchical structure of economic security was formed according to the results of the study. Each level is characterized separately. The essence of the concept of "economic security of the state" has been defined. Economic security of the state should be understood as such a condition of the national economy, in which it is possible to provide a high level of protection of the interests of each of its subjects from the negative impact of external and internal threats. The main components of the economic security of the state are identified, which include: financial, social, demographic, innovative, investment, food, energy and technological. The process of achieving a high level of economic security of the state by ensuring security for each of its components is presented.
\end{abstract}

Citation: Golovko Vladyslav. (2019) Essential Characteristics of the Economic Security of the State and its Main Components. World Science. 11(51), Vol.3. doi: 10.31435/rsglobal_ws/30112019/6778

Copyright: (C) 2019 Golovko Vladyslav. This is an open-access article distributed under the terms of the Creative Commons Attribution License (CC BY). The use, distribution or reproduction in other forums is permitted, provided the original author(s) or licensor are credited and that the original publication in this journal is cited, in accordance with accepted academic practice. No use, distribution or reproduction is permitted which does not comply with these terms.

Introduction. We live in a time of accelerated globalization of socio-economic relations and transformation processes, which not only contribute to positive changes, but also form new challenges and threats to our national economic security.

Ukrainian economy has suffered significantly over the past five years, and the process of full-fledged European integration is still incomplete. A significant number of threats and dangers contribute to such a development of events, exercising a negative impact on the national security system of our country.

The dynamics of the external environment is very unstable and difficult to predict, therefore, overcoming uncertainty and completing the process of European integration for the economic security of Ukraine today is a priority. That is why the study of the problems of ensuring the economic security of the state is so relevant. An important basis in this is the awareness of its essence and significance, which is extremely important in the context of world changes.

Literature review. Today, research of the economic security of the state are studied by a significant number of leading scientists, in particular L. Abalkin, A. Arkhipov, E. Bukhvald, A. Bandurka, B. Buzan, T. Vasiltsiv, A. Vlasyuk, V. Geyets, A. Gorodetsky, B. Grier, B. Gubsky, A. Gumeniuk, M. Ermoshenko, T. Iefymenko, Y. Zhalilo, Z. Zhivko, K. Kalmuk, G. Kozachenko, A. Korystin, S. Lazurenko, A. Lyashenko, A. Lepikhov, H. Maull, K. Murdoch, I. Migus, V. Muntiyan, N. Nizhnik, A. Novikova, G. Pasternak-Taranushenko, A. Piskunov, V. Predborskaya, V. Savin, O. Sylkin, V. Senchagov, M. Statkevich, A. Sukhorukov, A. Shtangret and others.

Paying tribute to the scientific and practical value of the research results of the aforementioned scientists, it should be noted that in the scientific literature there is still no one general idea about the essence of the economic security of the state and its main components. 
The main purpose of the study. The main objective of the study is to substantiate the essence of the economic security of the state and its main components.

Results and Discussions. Economic security as an independent term began to separate from the concept of "security" with the advent of a civilized state system. The first accurate descriptions of this period, as well as bringing the importance of state support for this type of security are given in the work of Plato "Polytea".

The concept of economic security in its usual form appeared in Western Europe at the end of the XII century and was interpreted as a state of absence of threats and dangers for the main social institutions of the state. At the state level, the basic tenets of the modern understanding of the concept of "economic security" were first adopted in the USA in 1947 during the admission of the "Act of National Security" [1].

In subsequent years, all civilized states in their own official documents outlined the main features of ensuring their own economic security. From 1997 to 2010, a number of documents were adopted in the world (the Paris Charter for a New Europe, the modernization of the Vienna Document and others), which noted the concept of "economic security" at the international level.

Today, the concept of "economic security" can no longer exist solely within one country, due to the intensification of globalization and democratization processes in the world.

As T. Iefymenko [2, p.35] notes, sustainability from state-owned economies is under pressure from comprehensive financialization and destabilization trends. Challenges to harmonize efforts to eliminate contradictions in the norms and rules of countries that aim at the general tasks of inclusive uplift and produce targeted leverage for their implementation, necessitate coordination of the environmental impact of the factors of interest of economic agents at all levels.

The development of safety without having expanded the essence of economic security so much, now it is considered at the mega-, macro-, meso- and micro-levels. Scientists have not yet reached a consensus on the hierarchical ordering of levels of economic security.

So, for example, A. Lyashenko, B. Pleskach and V. Bantush [3] distinguish local, regional, national, international and global economic security. The main problem of such a hierarchical structure of economic security is the lack of detail for each level. In more detail, the level of economic security is presented in the work of A. Chubukov and T. Voronkova [4, p. 5], which highlight: global economic security; international economic security; national economic security; economic security of the regions; economic security of the enterprise; economic security of the individual.

Based on the results of a generalizing analysis, we have formed our own vision of the hierarchical structure of economic security (Fig. 1).
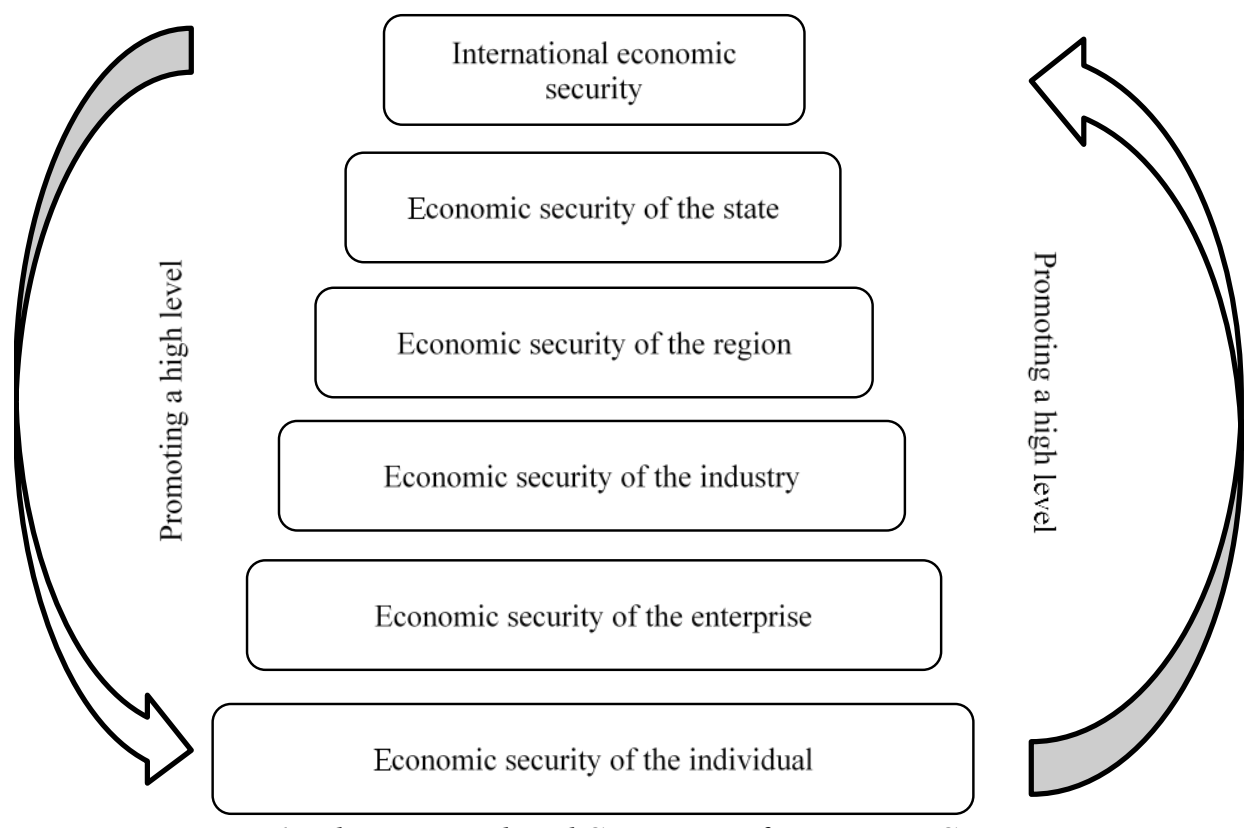

Fig. 1. The Hierarchical Structure of Economic Security

Formed by the author

We agree with the statement of T. Ivanyuta and A. Zaichkovsky [5, p.5], that international security is a set of international conditions for the coexistence of agreements and institutional structures, according to which each country member of the world community should be provided with the possibility of free 
choice and implementation of its own strategies for economic and social development, while eliminating external pressure and gaining full understanding, non-interference and mutual assistance from other states.

Regarding the economic security of the region, V. Geyets, N. Kizim, T. Klebanova and O. Chernyak [6] consider the concept of "economic security of the region", treating it as a relatively independent system for regional governments.

In our opinion, the economic security of the region should be regarded as a state in which the protection of the economic interests of each regional entity is ensured through the application of appropriate mechanisms and institutions.

According to L. Goroshkova [7, p.115], "economic security of the industry" should be understood as a system that is in a state of dynamic equilibrium with constant characteristics, as a result of which corporate regulation of industries and the national economy as a whole is ensured, which ultimately leads to increase the level of financial and economic security of the state.

The economic security of the industry should be such a state of a single industry in which safe development conditions are achieved for each socio-economic system.

With regard to the economic security of the enterprise, the interpretation provided by L. Khudoley [8] is accurate. He believes that the economic security of the enterprise is a state of protection of the vital interests of the enterprise from real and possible sources of dangers or economic threats.

We agree that the economic security of the individual is considered by the authors [9] as a state of human life, in which legal and economic protection of his interests is ensured, and basic constitutional rights are respected.

Each level of economic security in a hierarchical structure is very important and closely interacts with others, however, it is the economic security of the state that acts as a kind of "transitional" level that combines international security and economic security of such micro levels as regions, enterprises and individuals.

Today, there are a large number of views of scientists on the definition of "economic security of the state" (Fig. 2).

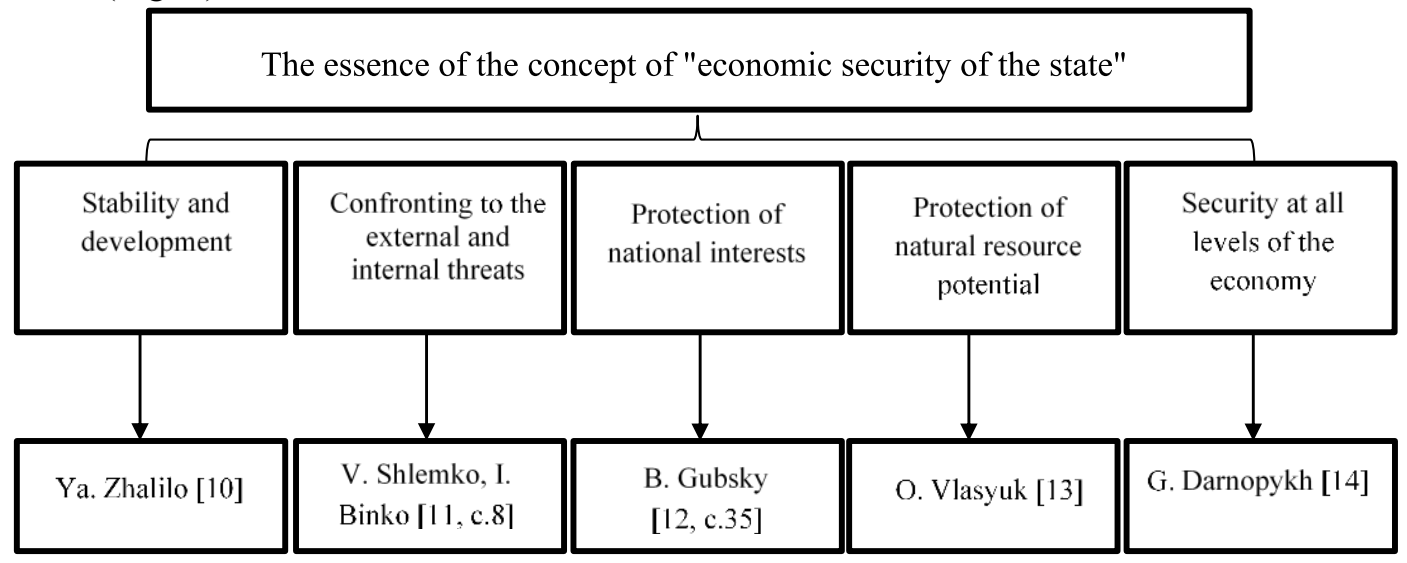

Fig. 2. The main approaches to the essence of the concept of "economic security of the state" Formed by the author

According to A. Bandurka, V. Dukhov, K. Petrova, I. Chernyakov, this term should be understood as the ability of the economic system to resist the negative influence of objective and subjective factors to achieve the established macroeconomic development goals of post-industrial countries [15, p. 64].

A. Stepanenko and M. Gerasimov [16, p. 44], considering the concept of "economic security of the state" as a state of the country's economy, ensures its external independence and internal stability. As the state of the country's economy is protected from dangerous actions, which can be both a consequence of the influence of various factors, and stochastic natural phenomena, this term is interpreted by G. Darnopykh [14].

In our opinion, the economic security of the state should be understood as such a state of the national economy, in which it is possible to ensure a high level of protection of the interests of each subjects from the negative impact of external and internal threats.

The economic security of the state is a condition that embodies a large number of structural components, each of which, through effective management, allows you to achieve the desired level of security.

Today, there is no one list accepted by all of the components of the state's economic security. An extensive list of the components of the state's economic security was presented by V. Muntiyan [17, p.459]: foreign economic, raw material resources, energy, financial, military-economic, technological, food, social, demographic, environmental and innovative-technological. 
As a result of our study, we have identified the main structural components of the economic security of the state (Table 1).

Table 1. The Main Structural Components of the Economic Security of the State

\begin{tabular}{|c|c|}
\hline Component of economic security of the state & Component nature \\
\hline Financial security of the state & $\begin{array}{l}\text { the condition of the financial system of the state in } \\
\text { which crisis development is not allowed and } \\
\text { effective financial growth is ensured }\end{array}$ \\
\hline Investment security of the state & $\begin{array}{l}\text { the condition of investment climate protection in the } \\
\text { country from external and internal destabilizing factors }\end{array}$ \\
\hline Social security of the state & $\begin{array}{l}\text { the ability of the state to protect its own social } \\
\text { interests, to ensure a decent and safe standard of } \\
\text { living for its population }\end{array}$ \\
\hline Energy security of the state & $\begin{array}{l}\text { the condition of protection from the negative impact } \\
\text { of factors of the external and internal environment of } \\
\text { the functioning of the fuel and energy complex }\end{array}$ \\
\hline Demographic security of the state & $\begin{array}{l}\text { the condition in which the demographic balance of society } \\
\text { is achieved under the negative influence of certain factors }\end{array}$ \\
\hline Innovative security of the state & $\begin{array}{l}\text { ensuring the protection of scientific and innovative } \\
\text { achievements for counteracting the negative impact } \\
\text { of the external and internal environment }\end{array}$ \\
\hline Food security of the state & $\begin{array}{l}\text { adequate food security and the ability to guarantee } \\
\text { stability in society }\end{array}$ \\
\hline Technological security of the state & $\begin{array}{l}\text { state of ensuring safe conditions for technological } \\
\text { development in the country in order to increase } \\
\text { competitiveness in the international arena }\end{array}$ \\
\hline
\end{tabular}

Formed by the author

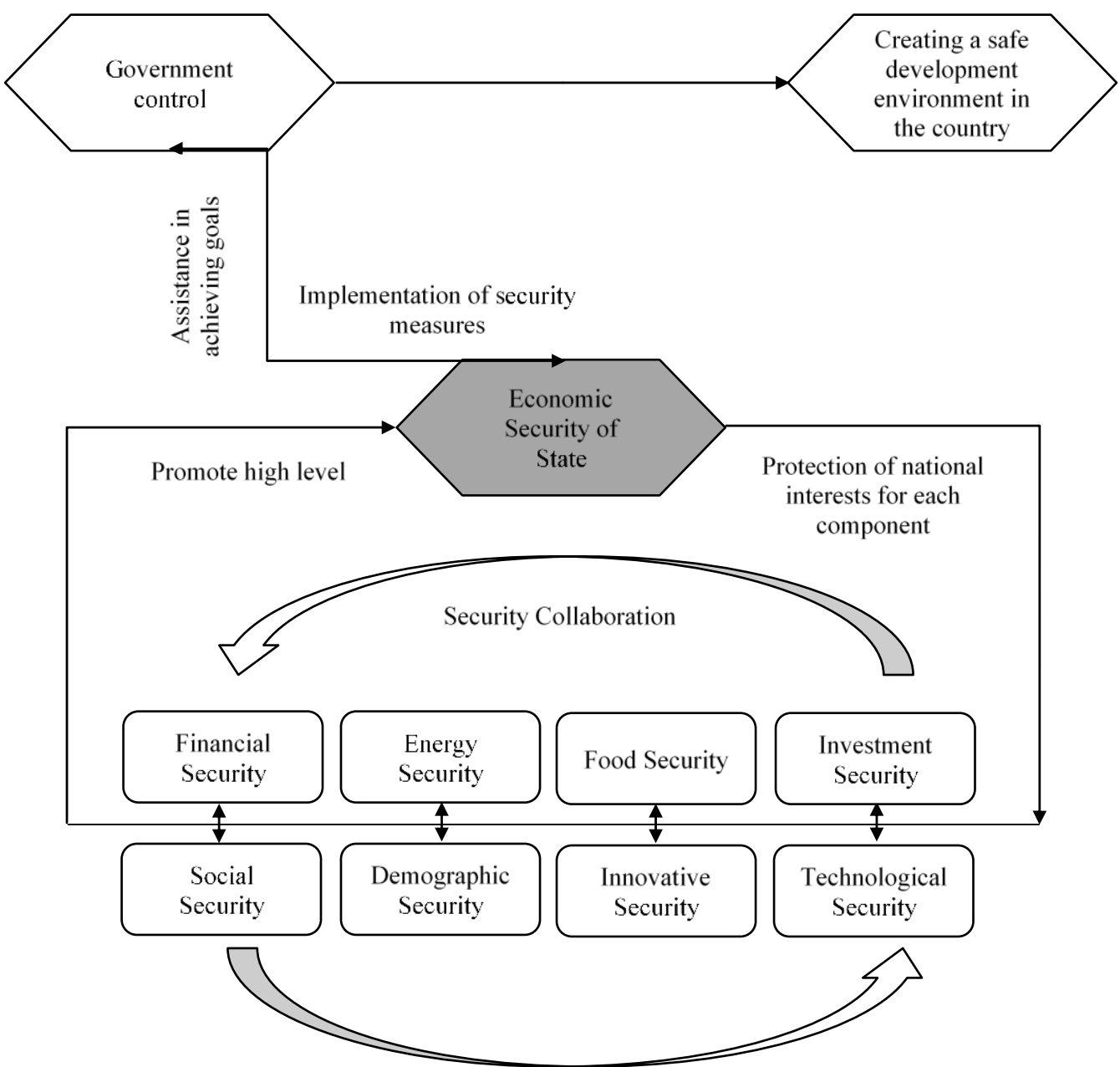

Fig. 3. Achievements of economic security of the state due to its main components Developed by the author 
Today it is impossible to talk about effective public administration without creating a safe development environment. It is the achievement of the state's economic security that is capable to create this kind of conditions, but for this it is necessary to fulfill a number of tasks. One of these tasks is to achieve a high level of security in all its structural components (Fig. 3).

The economic security of the state is different from any other level of security, and therefore requires a completely different approach to the provision process. The negative influence of the external and internal environment, a large number of components and other levels of security, all this and much more must be taken into account in the process of achieving the economic security of the state.

Today, there are a number of "critical" problems that substantially threaten the economic security of Ukraine, in particular: high inflation; lack of competitiveness of domestic enterprises; weak investment policy; high unemployment and corruption. All of these problems require immediate government intervention to ensure economic security.

Conclusions. Perhaps the most important place in the main hierarchy of economic security is precisely the security of the state, through effective public administration, it can help achieve a high level of security at any other level. Today, each component of the economic security of the state has long gone beyond a close scientific framework, and is independently attracting the attention of leading non-profit providers around the world. Therefore, the issues of ensuring the economic security of the state are gaining an even broader nature and therefore require further attention to the search for new methods to achieve a high level of this type of security, taking into account the significance of each of its components.

\section{REFERENCES}

1. MacFarlane, S. Neil; Yuen FoongKhong (2006). S. Neil, MacFarlane; Yuen FoongKhong. eds. Human security and the UN: a critical history. United Nations intellectual history project (illustrated ed.). Indiana University Press. ISBN 9780253218391. Retrieved 23 September 2010.

2. Current Problems of Financial Management: Global Trends and National Practice / ed. by T. Iefymenko; SESE "The Academy of Financial Management". Kyiv, 2018. - 496 p.

3. Lyashenko A.N., Pleskach B.V., Bantush V.K. Economic security and national competitiveness in the context of globalization // Culture of the Black Sea peoples. 2009. No. 161. pp. 113-118.

4. Chubukova A.Yu., Voronkova T.E. The system of economic security (ecosestate): essence, structure. Effective Economy, 2014. URL: https://knutd.edu.ua/publications/pdf/Ukrainian_editions/Chubukova2015052803.pdf (accessed: 11/27/2019).

5. Ivanyuta, T. N., Zaichkovsky A.A. Economic security [Text]: textbook. allowance. K.: Center for Educational Literature, 2007. P.5.

6. Geyets V.M., Kizim N.A., Klebanova T.S., Chernyak O.I. Modeling Economic Security: Monograph. M .: INZHEK, 2006. 240 p.

7. Goroshkova L.A. Analysis of the determinants of economic security of sectors of the national economy // University Economic Bulletin. Economic Bulletin of Pereyaslav-Khmelnitsky State Pedagogical University. G. Pans. 2012. Issue. 19. pp.113-129.

8. Khudoley L. N. The components of economic security of business entities. Effective economy. 2011. URL: http://www.economy.nayka.com.ua/index.php?operation=1\&iid=455 (accessed: 11.28.2019).

9. Korystin A.E., Baranovsky A.I., Gerasimenko L.V. Economic security: textbook. allowance. M .: KNUVS. $2010.368 \mathrm{~s}$

10. Zhalilo Y. Strategy for ensuring economic security of Ukraine. Priorities and problems of implementation // National Security Strategy of Ukraine in the context of the international community experience. M .: Santisanga. 2001.222 p.

11. Shlemko V.T., Binko I.F. The economic security of Ukraine: the nature and directions of support. M .: NISI, 1997.144 p.

12. Gubsky B.V. Economic Security of Ukraine: measurement methodology, state and support strategy. K., 2001.122 p.

13. Vlasyuk O. S. Theory and practice of economic security in the system of science of economics; Nat Institute of prob. Int. Security Council of nat. security and defense of Ukraine. K., 2008. 48 p.

14. Darnopykh G. Yu. Economic security of the state in a transformational economy: Abstract. dis. to receive sciences. degree of cand. econ. Sciences: special. 01/08/01 "Economic theory"; Kharkiv. state un-t H., 1999. 21 p.

15. Bandurka AM, Dukhov V.E., Petrova K.Ya., Chernyakov IM Fundamentals of economic security: [textbook]. Kharkov: NUVD, 2003.236 s.

16. Stepanenko A. Gerasimov M. Assessment of economic security of Ukraine and its regions // Regional Economy. 2002. No. 2. pp. 39-54.

17. Muntiyan, V.I. Economic Security of Ukraine [Text]. K.: KVITs, 1999. 446 p. 